\title{
PENGGUNAAN ANGGAH UNGGUHING BASA BALI; SEBUAH KESANTUNAN DAN PENANDA KELAS SOSIAL MASYARAKAT BALI
}

\author{
I Nyoman Duana Sutika \\ Prodi Sastra Bali \\ Fakultas Ilmu Budaya, Universitas Udayana
}

\begin{abstract}
:
Balinese language with its leveling still intensively used by the Balinese people. Anggah-ungguhing basa (the languages levels) mostly used in the traditional event, and in special events, such as a workshop, conference, and seminars. It also used when the Balinese communicate with elder and strangers. Generally for most Balinese language regarded as the mother language, especially those who live in rural areas.Since the lack of young generation interest, the use of Balinese language levels has decreased.Intead of complicated language levels in Balinese, the young Balinese prefer to use Indonesian, as its more practical and easier. On the other hand, the Balinese language levels, contain a value of modesty, courtesy, and manners, also be a symbol of social class in Balinese society. Communication is arranged based on a social class using fine andcoarse language.
\end{abstract}

Keywords: Balinese language, anggah-ungguhing basa, modesty value, and social class

\section{Pendahuluan}

Bahasa Bali sebagai bahasa ibu atau merupakan bahasa pertama bagi sebagian besar masyarakat Bali dipakai secara luas oleh masyarakatnya. Keberadaan bahasa Bali memiliki variasi yang cukup rumit terutama karena adanya tingkat-tingkat pemakaian bahasa yang disebut anggah ungguhing basa (sesuai dengan hasil Pasamuhan Agung Bahasa Bali tahun 1974) dan atau sebutan lainnya. Dalam perkembangannya sejak zaman Bali Kuno, bahasa Bali belum mengenal anggah ungguhing basa. Bahasa Bali mengalami perkembangan ketika terjadi hubungan antara Bali (Hindu) dengan kebudayaan Jawa (Hindu) berjalan secara intensif. Pengaruh Jawa yang begitu besar telah mempengaruhi kebudayaan Bali termasuk sistem kebahasaan, yakni anggah ungguhing basa yang tumbuh seiring suburnya zaman kerajaan di Bali.

Bahasa Jawa Tengahan dan bahasa Jawa Baru adalah bahasa yang mengenal sistem undausuk yang merupakan embrio perkembangan bahasa Bali akibat terjadinya akulturasi budaya antara Jawa dan Bali. Pada awal tumbuhnya sistem pemakaian unda-usuk/anggah ungguhing basa Bali amatlah ketat ditanamkan pada pelapisan sosial masyarakat Bali dengan segala sanksi dan aturan yang mengikatnya. Tumbuh suburnya anggah ungguhing basa Bali seiring zaman kerajaan yang membagi dan mengkotak-kotakkan masyarakat Bali menjadi empat bagian; brahmana, ksatria, wesia, dan sudra. Urutan pertama sampai ketiga umumnya disebut tri wangsa/wang menak dan yang lain sering disebut nak jaba. Secara kuantitas keberadaan tri wangsa hanyalah terdiri dari kurang lebih 15\% masyarakat Bali. Walaupun demikian dalam kehidupan sosial umumnya mereka mampu mengambil peran lebih banyak terutama dalam pemerintahan dan menghegemoni wang sudral jaba karena beberapa alasan; pertama, keberadaan tri wangsa/wang (orang) menak secara tradisional berasal dari keturunan ningrat/penguasa, lahir dari keturunan orang-orang yang mempunyai kemampuan ekonomi di atas rata-rata orang jaba. Kedua, pada zaman dahulu wang menak selain sebagai penguasa juga orang-orang dari keturunan terpilih sebagai pendamping raja (ksatria) dan pendamping kerohanian raja (brahmana) sehingga hidupnya lebih sejahtera. Wajarlah mereka mempunyai kemampuan ekonomi lebih dibandingkan dengan keturunan orang biasa (jaba) secara umum. Dengan demikian kelompok wang menak lebih mempunyai peluang untuk mengembangkan diri dalam berbagai aspek kehidupan termasuk meningkatkan kualitas diri di dalam menuntut ilmu pengetahuan untuk menjadi orang unggul sehingga mampu menduduki posisi/jabatan di pemerintahan atau intansi/lembaga lainnya.

Salah satu hegemoni yang sampai saat ini masih mencekoki dan melekat dalam kehidupan masyarakat Bali (Hindu) adalah penggunaan 
anggah ungguhing basa yang dalam perkembangannya kurang diminati oleh generasi muda. Kenyataannya banyak generasi muda sekarang ini sengaja menghindar dari penggunaan bahasa Bali karena takut salah dalam menggunakan anggah ungguhing basa tersebut. Mereka lebih memilih bahasa Indonesia yang bersifat netral dan mudah dipahami. Suryati (2016: 538) dalam tulisan makalahnya menyebutkan bahwa kecendrungan penutur menghidar dari pemakaian anggah ungguhing basa untuk menggantinya dengan bahasa Indonesia disebabkan oleh adanya rasa gengsi seseorang untuk menggunakan bahasa Bali dan pemakaian bahasa Indonesia dianggap menaikkan status sosial dalam masyarakat.

Akhirnya menjadi momok bagi generasi muda ketika pada momentum tertentu mewajibkan untuk memakai bahasa Bali dengan sor singgih basa. Banyak generasi muda yang menghindar ketika misalnya ditugasi nangkil ke geria untuk urusan upacara yadnya, dan hanya segelintir orang yang sanggup untuk melakukan tugas itu. Mereka lebih banyak menolak karena ragu dan kawatir tidak mampu berkomunikasi menggunakan anggah ungguhing basa Bali. Begitu juga untuk urusan upacara yadnya lainnya yang memerlukan keahlian berbahasa Bali. Ini menandakan bahwa bahasa Bali dengan anggah ungguhing basanya masih dianggap menjadi faktor kendala (momok) dalam kehidupan masyarakat Bali.

Diakui bahwa bahasa Bali sampai saat ini masih intensif digunakan oleh masyarakat Bali, terbatas pada bahasa Bali lumrah yang sering juga disebut bahasa Bali kepara/ketah. Kebanyakan masyarakat Bali enggan untuk belajar dan menggunakan bahasa Bali yang bertingkat-tingkat karena selain sulit juga dianggap menghambat komunikasi dua arah. Pada satu sisi memang penggunaan bahasa Bali dengan aturan anggah ungguhing basa dianggap memiliki nilai kesantunan, kesopanan, dan tata krama bagi sebuah tatanan etika masyarakat Bali sehingga kesalahan di dalam penggunaannya dianggap tidak santun, tidak sopan dan juga tidak bertata krama. Komunikasi dua arah antara tri wangsa umumnya dengan wangsa sudra/jaba sering harus menggunakan bahasa Bali bertingkat ini. Lebihlebih terhadap warna brahmana (pandita, sri mpu,rsi) dan sulinggih lainnya hendaknya komunikasi dibangun/dijalin dengan menggunakan bahasa yang bertingkat (anggah ungguhing basa Bali). Dianggap tidak santun (ten anut ring sesana) seorang jaba yang melakukan panangkilan ke gria menggunakan bahasa Bali lumrah karena dianggap melanggar tata kesopanan bahkan melecehkan. Seorang sulinggih merupakan strata sosial tertinggi dari empat warna yang ada di Bali sehingga kumunikasi yang dibangun hendaknya menggunakan bahasa Bali halus untuk menunjukkan rasa hormat. Begitu juga seorang panjak (jaba umumnya) yang tangkil (menghadap) ke puri secara inten akan menggunakan bahasa Bali halus sebagai wujud tunduk panjak terhadap raja dan hegemoni raja terhadap panjak. Inilah refleksi kehidupan sosial budaya masyarakat tradisional Bali yang masih tercermin pada kehidupan sekarang.

Pemakaian bahasa Bali yang bertingkat dengan memakai anggah ungguhing basa Bali) selain menunjukkan kesantunan juga menjadi penanda kelas sosial masyarakat di Bali. Komunikasi yang dibangun dengan bahasa Bali bertingkat ini senantiasa didasarkan atas status sosial seseorang dalam masyarakat. Seseorang yang berasal dari golongan bawah menurut stratifikasi sosial masyarakat Bali disarankan memakai bahasa Bali dengan tingkat yang lebih halus terhadap golongan atas dan golongan atas tidak diwajibkan menggunakan bahasa Bali halus atau boleh menggunakan bahasa Bali kasar terhadap golongan bawah. Ini terutama terjadi pada sistem tradisi budaya feodal yang menganggap sebagai etika budaya masyarakat. Secara tradisi triwangsa dianggap sebagai golongan atas, tetapi dalam kaca mata masyarakat modern golongan atas ini didominasi oleh hartawan (orang kaya), dan pejabat lainnya.

Status sosial dalam perspektif kewangsaan dijadikan tolak ukur untuk menentukan tingkat pemakaian bahasa Bali. Golongan wangsa sudra dengan status sosial terendah harus menggunakan bahasa Bali halus terhadap golongan wangsa yang lebih tinggi (tri wangsa). Apabila hal ini dilanggar akan terjadi disharmoni komunikasi di dalamnya, membuat ketersinggungan bagi golongan tertentu. Di era sekarang hal ini masih sering terjadi, hanya saja masyarakat Bali umumnya enggan menjadikan kasus seperti ini sebagai masalah yang panjang. Tetapi golongan tertentu masih tetap menganggap dirinya mempunyai strata sosial yang lebih tinggi dari golongan lainnya sehingga penggumaan anggah ungguhing basa Bali ini menjadi salah satu penanda perbedaan kelas dan status sosial seseorang dalam masyarakat Bali. 
Pengalaman menggelitik pernah dialami penulis di kisaran tahun 1986 saat perjalanan pulang kampung di desa Antosari, kecamatan Selemadeg, Tabanan. Di perjalanan, tepatnya di areal persawahan bertemu dengan seseorang yang nampak seperti petani tua menuju arah persawahan. Sebagaimana etika orang desa, penulis sempat menyapa orang tua tersebut dengan kalimat sapaan biasa yang umumnya orang desa lakukan. "Bapa kal kija ne?" "Kal ke carik"?. Orang tua tersebut tidak langsung menyahut atau merespon sehingga penulis merasa perlu mengulangi sapaan tersebut dengan kalimat yang sama takut pertanyaan sebelumnya tidak didengar. Betapa terkejutnya ketika orang tua tersebut justru menunjukkan peringai kemarahan yang luar biasa dan tersinggung. Jawabannya pun sungguh sangat ironis "Sing ngelah bapa jumah, tiang nak gusti tawang"?. Jawaban pertanyaan ini adalah hasil komunikasi yang mencerminkan realita sosial, bukti dari sisa keangkuhan rezim yang masih mungkin terjadi sampai sekarang ini. Keadaan ini menandakan seseorang merasa tingkat wangsanya lebih tinggi dari orang lainnya atau lawan bicaranya sehingga tidak menerima sapaan sebagai orang biasa (jaba) karena merasa direndahkan atau dilecehkan. Penanda komunikasi dengan memakai anggah ungguhing basa Bali inilah yang akan dibahas dalam tulisan di bawah ini.

\section{Metodologi}

Data bersumber dari pola hubungan dan interaksi sosial yang terjadi dalam kehidupan masyarakat Bali yang di dalamnya terjadi dialog antar sesama masyarakat Bali. Dari dialog tersebut menghasilkan klasifikasi dan klasterisasi kebahasaan, yang di antaranya menimbulkan konflik sosial karena pola komunikasi dianggap tidak relevan. Data yang diperoleh dianalisis dan disajikan dengan menggunakan analisis deskriptif kualitatif dan teknik simak. Data data tersebut diidentifikasi dan diklasifikasikan serta diinterpretasikan sehingga menghasilkan suatu hasil penelitian yang dapat dipertanggungjawabkan secara ilmiah.

\section{Penggunaan Anggah Ungguhing Basa Bali; Sebuah Kesantunan Berbahasa Bali}

Bahasa Bali dengan pemakaian bertingkattingkat mendapat banyak sebutan dari para ahli, di antaranya: 1) Kersten dalam bukunya Tata Bahasa Bali (1970) menyebut dengan Warna-Warna Bahasa; 2) Ida Bagus Udara Naryana menyebut dengan Anggah Ungguhing Basa; 3) I Gusti Ngurah Bagus menyebutnya dengan Bentuk Hormat. Tingkat-tingkat pemakaian bahasa Bali ini pada intinya disebabkan oleh adanya empat situasi terhubung dengan sistem kasta atau wangsa yang ada di Bali. Wangsa brahmana, ksatria, dan wesia dikelompokkan sebagai masyarakat terhormat yang oleh Kersten (1970) disebut "golongan atas" dan wangsa keempat (sudra) dikelompokkan menjadi "golongan bawah". Ini merupakan bentuk pengelompokan masyarakat Bali secara tradisional yang sekaligus berpengaruh terhadap tingkattingkat penggunaan/pemakaian bahasa (dialog) yang terjadi di dalamnya.

Setiap pelaku dialog diawali oleh pengenalan dirinya terhadap lawan bicaranya serta siapa yang dibicarakan. Hal ini untuk menghindari terjadi kesalahan pemakaian bahasa dalam dialog tersebut. Apabila seseorang berasal dari golongan sudra wangsa melakukan percakapan dengan orang se-wangsa maka bahasa Bali yang dipakai adalah bahasa lumrah/kasar/ketah/lepas hormat, tetapi ketika menyebut bagian/orang menak maka akan dipilih bahasa yang tingkatannya lebih halus (basa alus singgih) sebagai wujud hormat kepada wangsa yang dianggap lebih tinggi. Begitu juga seseorang (wangsa sudra) ketika berdialog dengan tri wangsa (wang menak) akan semakin tinggi variasi dan tataran bahasa yang digunakannya. Orang sudra selalu menggunakan bahasa yang tingkat pemakaian bahasanya lebih halus kepada orang menak untuk menghormati lawan bicaranya. Begitu juga ketika menyebut orang yang berasal dari kelompok orang menak (tri wangsa) sewajarnya menggunakan bahasa Bali halus. Inilah norma sopan santun dan deskripsi tingkat-tingkat bicara yang oleh Bagus (2009: 91) dianggap sebagai sistem budaya yang berlaku di dalam masyarakat Bali.

Percakapan yang dianggap santun ketika seseorang dari golongan yang lebih rendah mampu memilih tataran bahasa yang lebih halus untuk lawan bicara yang golongan wangsanya dianggap lebih tinggi. Kesalahan pemilihan atau pemakaian bahasa dalam percakapan tersebut dapat menimbulkan disharmoni terhadap dialog tersebut. Bisa menimbulkan ketersinggungan dan wak purusia (jabag atau jadag) lainnya. Jabag adalah kata-kata atau ungkapan bahasa yang sengaja atau tidak sengaja diucapkan oleh seseorang dari 
golongan bawah (sudra wangsa) kepada orang yang lebih tua atau orang yang wangsanya lebih tinggi untuk tujuan tertentu terhadap golongan atas. Kesalahan yang terjadi hanya pada golongan yang lebih rendah, karena golongan atas dianggap dapat menggunakan bahasa yang diinginkannya tanpa kesalahan. Golongan menak juga merasa tidak wajib menggunakan bahasa Bali halus karena berdialog dengan orang yang dianggap wangsanya lebih rendah. Diskriminasi kebahasaan ini telah berlangsung sejak beberapa puluh tahun yang sampai kini masih tetap berlangsung apabila terjadi percakapan antar wangsa. Menurut Bagus (2009: 92) ketika masih berlakunya pengadilan Raad Kerta di Bali, penyimpangan atau pelanggaran terhadap norma sopan santun berbahasa dapat diajukan ke pengadilan dan pelanggaran itu dapat dikenakan hukuman berdasarkan ketentuan agama (wak parusia) itu sendiri

Dialog akan mengalami kesulitan ketika sulitnya menemukan kata-kata atau kalimat sepadan dalam bentuk hormat terhadap lawan bicara. Apalagi generasi muda saat ini cendrung tidak banyak yang tertarik untuk serius belajar berbahasa Bali yang bertingkat-tingkat tersebut karena selain sulit juga tidak mendatangkan keuntungan secara finansial. Kesulitan terjadi tidak hanya pada tataran bahasa, tetapi karena munculnya kelompok elit baru, seperti pengusaha, pejabat dan orang kaya yang juga menjadi golongan atas pada pelapisan sosial masyarakat Bali modern. Ini artinya wangsa menak tidak lagi berada di menara gading karena stratifikasi sosial masyarakat Bali tradisional mulai bergeser menuju stratifikasi masyarakat Bali modern dimana orang kaya/pengusaha mendapat tempat tersendiri di mata masyarakat. Kelas elite baru menurut Granoka, dkk (1996: 2) tidak lagi memperhitungkan kasta yang juga disegani dan dihormati oleh golongan bawah yang tercermin pula dalam pemakaian bahasanya.

Penggunaan anggah ungguhing basa Bali selain menunjukkan kecakapan juga diakui menjadi acuan kesantunan seseorang karena dianggap mampu melakukan percakapan berbahasa Bali yang bermartabat. Kesantunan menurut (CALD-2003) adalah berprilaku sesuai dengan kaidah sosial yang berlaku dalam masyarakat dan dapat menunjukkan kepedulian dan kepekaan terhadap perasaan orang lain (dalam Suryati, 2016: 544). Kesantunan berbahasa Bali dicirikan oleh penggunaan bahasa bertingkat yang lazim dipakai oleh orang yang baru pertama kali berkenalan dengan sesama orang Bali. Selain itu juga digunakan pada situasi resmi, seperti kegiatan keagamaan/adat, lokakarya, pasamuhan, sangkep/rapat banjar dan kegiatan sejenis yang berbau lokal. Seseorang yang baru saja bertemu, berkenalan dan melakukan dialog dengan sesama orang Bali baik se-wangsa atau lain wangsa selalu diawali dengan kata sapa berbahasa Bali halus. Ini menjadi penanda kesantunan orang Bali yang beretika dan memiliki sopan santun, meskipun tidak jarang dewasa ini percakapan diawali dengan bahasa Indonesia, kawatir lawan bicaranya bukan orang Bali. Hal ini banyak dilakukan terutama di daerah perkotaan karena keberadaan penduduk kota yang sangat heterogen yang warganya banyak berasal dari luar Bali.

\section{Pemakaian Anggah Ungguhing Basa Bali Sebagai Penanda Kelas Sosial Masyarakat Bali}

Sistem kasta di Bali dinyatakan Kerepun (2007: 140-155) selain dibentengi oleh mitos larangan amada-mada ratu, asisia-sisia, paham ajawera dan paham rajadewa juga diperkokoh oleh berbagai aturan dan larangan keras dalam tatalokacara bertutur kata atau tata tertib berbahasa Bali. Sistem atau hukum tata tertib berbahasa yang berlaku lebih ditekankan pada golongan bawah, sementara golongan atas hampir luput dari kesalahan aturan penggunaan anggah ungguhing basa tersebut. Kesalahan dalam penggunaan basa Bali yang sekaligus dianggap melanggar tata sopan santun hanya bagi golongan bawah. Tata tertib berbahasa Bali dengan penggunaan anggah ungguhing basa yang mempunyai konskuensi hukum tersebut hanya berlaku pada golongan rendah (sudra) dan tidak berlaku untuk golongan atas (tri wangsa). Inilah cermin arogansi kekuasaan dengan sistem kebahasaan dengan pemberlakuan anggah ungguhing basa yang mengandung ketimpangan sosial bahwa nilai "rasa" bahasa ditentukan oleh status sosialnya (kasta dan kedudukan).

Ketimpangan sosial dalam pemakaian anggah ungguhing basa Bali ini tercermin pada dialog yang terjadi antara golongan bawah dengan golongan atas. Secara normatif golongan bawah (jaba dan pelayan lainnya) di Bali wajib menggunakan bahasa yang konteksnya lebih halus kepada golongan atas. Sebaliknya golongan atas tidak wajib menggunakan bahasa halus dan bahkan 
dianggap wajar memakai bahasa Bali yang konteksnya lebih rendah/kasar. Golongan atas yang dimaksud tidak hanya tri wangsa (secara tradisional) tetapi termasuk elit baru, seperti pejabat dan orang kaya lainnya. Inilah salah satu bentuk arogansi kekuasaan yang berimplikasi pada pemakaian anggah-ungguhing basa Bali yang penggunanya disesuaikan dengan kedudukan dan atau status sosialnya di dalam masyarakat.

Penggunaan bahasa Bali yang menyimpang dari kaidah anggah unguhing basa sering menimbulkan konflik horizontal antar pemakainya, ketersinggungan yang berujung pada permusuhan/pertengkaran. Di zaman sekarang masih sering terjadi kesalahpahaman ini dimana golongan tertentu merasa dirinya dilecehkan/direndahkan atau tersingung ketika seseorang yang berasal dari golongan rendah, salah dalam menggunakan tatanan bahasa Bali. Oleh pengguna, kesalahan tersebut juga sering tidak disadari karena ketidaktahuannya, walaupun dalam beberapa kasus tidak jarang hal tersebut sengaja dilakukan untuk tujuan tertentu. Kenyataanya sampai sekarang masyarakat Bali masih dibelenggu oleh sisa-sisa sistem feodal yang mengharuskan seseorang berbicara dengan bahasa Bali halus kepada golongan atas.

Menurut Wiana (1993: 100-101) tri wangsa/kasta yang lebih tinggi di Bali cendrung sebagai kaum penguasa yang tetap ingin mempertahankan kekuasaannya dengan segala cara yang bisa mereka lakukan. Cara-cara yang dilakukan dibungkus dan dikaitkan dengan nilainilai kebenaran yang bersifat umum, sebagaimana wangsa dibungkus dengan sistem warna yang telah diterima umum oleh umat Hindu di Bali. Salah satunya adalah penggunaan anggah ungguhing basa Bali ini yang dianggap benar apabila telah mengikuti kaidah-kaidah kebahasaan sesuai dengan sistem kebahasaan yang betingkat-tingkat. Sistem ini sengaja dibuat kokoh yang menurut Kerepun (2007: viii) sebagai hasil rekayasa peradaban manusia Bali dengan menyebut aktor yang cerdas, didukung fakta tekstual sumbersumber lontar untuk memberi acuan pembenar sebagai payung hukum.

Di era feodal bahkan selain penggunaan anggah-ungguhing basa yang harus tepat (karena kesalahan bisa berakibat sanksi hukum), sikap dan adat seseorang golongan rendah terhadap golongan atas hendaknya menunjukkan sikap hormat, seperti matetanganan dan sikap hormat lainnya. Golongan bawah (sudra) apabila melakukan kumunikasi dengan tri wangsa hendaknya diikuti oleh sikap dan mimik yang menunjukkan kesopansantunan sebagai seorang bawahan. Apalagi seorang sudra yang datang (nangki)l ke geria dan atau ke puri untuk urusan tertentu harus madarsana (menunjukkan sikap yang sangat hormat dan sopan) dibarengi dengan tubuh membungkuk (matetanganan), wajah menunduk dan lalu duduk bersila di tempat yang lebih rendah sekaligus mengawali percakapan dengan bahasa santun/halus. Hubungan vertikal sebagai kawula (panjak) gusti (raja) yang absolut melekat dalam kehidupan sehingga kawula/panjak wajib melakukan apapun (sutinut) untuk kepentingan gustinya. Hubungan/kumunikasi yang terjalin seperti ini sama sekali tidak mencerminkan kesetaraan karena adanya hubungan vertikal antara golongan atas sebagai subjek dan golongan bawah sebagai objek.

Pemberian sanksi wak purusia terhadap kesalahan pemakaian bahasa Bali adalah sebuah bentuk arogansi legitimasi kekuasaan karena kesalahan dan penyimpangan hanya dikenakan pada kaum/golongan wangsa rendahan (jaba) saja sementara golongan atas luput dari sanksi tersebut. Walaupun kesalahan pemakaian bahasa Bali tersebut tanpa disengaja sehingga yang bersangkutan harus mendapat sanksi atas kesalahannya. Di zaman dulu seorang anak yang berani menyebut "nama" orang tuanya sendiri secara vulgar atau menyebut anggota tubuh orang tuanya dengan bahasa kasar akan mendapat sanksi moral dengan sebutan tulah/langgah, yaitu orang yang telah dianggap melanggar norma-norma etika dan susila. Dalam kalimat misalnya "Bapan icange tendasne matatu" (Ayah saya kepalanya terluka). Untuk menyebut "kepala ayah" dengan bahasa yang lugas dan pantas harusnya diucapkan "Bapan icange sirahne/duurne matatu".

Pernyataan mengelitik dari Kerepun (2007: 151-152) bahwa di seluruh dunia mungkin hanya di Bali saja ada kesalahan berbahasa Bali haluskasar akan mempunyai akibat hukum, seperti wak parusia, yaitu kesalahan dalam penggunaan bahasa ketika terjadi komunikasi antara golongan bawah (sudra wangsa) dengan golongan atas (tri wangsa). Sanksi diberlakukan hanya untuk golongan bawah karena golongan atas khususnya raja dianggap mewakili hukum itu sendiri yang tidak bisa dibantah sehingga golongan bawah (sudra) hanya menjadi objek yang menerima sanksi atas kesalahan, yang ditentukan oleh penguasa (raja). Di antara pengajegan kasta lainnya justru penggunaan anggah ungguhing basa ini yang 
paling kuat melekat pengaruhnya secara psikis, dibandingkan dengan bentuk pengajegan kasta/wangsa lainnya, karena mampu mencekoki alam pikiran orang Bali melalui bahasa. Kesalahan dalam penggunaan anggah ungguhing basa ini berakibat hukum yang sanksinya bisa sangat berat atau hukuman secara psikologis lainnya apalagi penghinaan terhadap golongan kasta yang tertinggi (brahmana).

Salah satu wadah pengajegan anggah ungguhing basa Bali adalah melalui wahana pertunjukan kesenian tradisional Bali, menjadi ladang subur pesemaian pemakaian anggah ungguhing basa yang mengacu pada wangsa atau kasta itu sendiri. Di dalam kesenian tradisional Bali, seperti arja, topeng, gambuh, drama gong dan sendratari di dalamnnya kental dengan penggunaan anggah ungguhing basa yang dijadikan norma-norma kesenian tradisional Bali. Narasi ceritanya juga mengambil keadaan era feodal sekaligus tatanan sosial masih mengadopsi kehidupan di zaman kerajaan dengan pemakaian anggah ungguhing basa Balinya.

Dalam perkembangannya, intensitas pemakaian anggah ungguhing basa Bali dewasa ini telah mengalami penurunan drastis terutama oleh generasi muda yang cendrung memilih bahasa kumunikasi yang lebih mudah dan sederhana, yaitu bahasa Bali biasa/ketah/lumrah atau bahasa Indonesia. Anggah ungguhing basa Bali ini hanya digunakan pada ranah tertentu dan momentum yang berkaitan dengan kegiatan keagamaan, adat serta aktivitas lainnya, seperti pesamuhan, saresehan, dan seminar yang bertema lokal Bali. Generasi muda umumnya juga kurang tertarik mendalami bahasa Bali yang bertingkat ini. Selain sulit, penggunaan anggah ungguhing basa ini akan mengalami kerancuan ketika kasta yang lebih tinggi menjadi pelayan bagi golongan kasta yang lebih rendah yang menempati posisi elit baru sebagai golongan atas. Ini sekaligus menandakan bahwa derajat sosial seseorang di zaman sekarang ini tidak lagi semata ditentukan oleh golongan wangsa/kasta, tetapi lebih berorientasi pada pendidikan dan berujung pada kepemilikan materi/kekayaan. Seseorang yang lahir dari golongan kasta brahmana (tanpa bermaksud merendahkan) yang kesehariannya berprofesi sebagai buruh tani atau pelayan/bawahan tidak sekaligus mendapat penghormatan oleh seorang sudra wangsa yang kebetulan menjadi atasannya.

\section{Simpulan}

Norma sopan santun berbahasa yang dulunya sangat ketat, dewasa ini telah luluh dan mengalami pergeseran dengan adat baru yang dianggap lebih demokratis, termasuk norma sopan santun pada tingkat wicara telah mengalami degradasi disesuaikan dengan perkembangan zaman. Penggunaan anggah ungguhing basa Bali saat ini masih intensif digunakan terbatas pada kegiatan saresehan, lokakarya, dan seminar yang berbau lokal, dan aktivitas adat serta agama. Pada tataran kumunikasi masyarakat Bali lebih banyak memilih bahasa Bali lumrah, kecuali dalam dialog khusus yang dilakukan oleh orang yang belum saling mengenal atau terhadap orang yang dihormati.

\section{Daftar Pustaka}

Bagus, I Gusti Ngurah.2009. Perubahan Pemakaian Bentuk Hormat Dalam Masyarakat Bali Sebuah Pendekatan Etnografi Berbahasa. Denpasar: Balai Bahasa.

Granoka, Ida Wayan Oka, dkk. 1996. "Tata Bahasa Baku Bahasa Bali”. Denpasar Balai Penelitian Bahasa.

J Kersten SVD. 1970. "Tata Bahasa Bali". Denpasar: Percetakan Arnoldus.

Kerepun, Made Kembar. 2007. Mengurai Benang Kusut Kasta Membedah Kiat Pengajegan Kasta di Bali. Denpasar: PT.Empat Warna Kumunikasi.

Naryana, Ida Bagus Udara. 1984. "Tingkatan Anggah-ungguhing Basa Bali". Denpasar: Majalah Widya Pustaka No.4 Th.1984.

Suryati, Ni Made. 2016. "Keterkaitan Anggah Ungguhing Basa Bali dengan Kesantunan Berbahasa" dalam Prosiding Seminar Nasional Sastra dan Budaya, 27-28 Mei 2016 FIB Unud. 